\title{
Severe mammary fibroepithelial hyperplasia due to single injection of medroxyprogesterone acetate in two male cats
}

\section{Fabiana Azevedo Voorwald ${ }^{1^{*}}$ (B) Carlize Lopes $^{2}$ (B) Gabriel Coutinho Silveira ${ }^{1}$ (D) Daniela Tavares Lima $^{3}$ (D) Maria de Fátima Cotta da Silva ${ }^{1}$ (i) Natália Brioschi Andreão ${ }^{1}$ (i) Gilson Hélio Toniollo ${ }^{4}$ iD}

${ }^{1}$ Departamento de Veterinária, Universidade Federal de Viçosa (UFV), 36570-000, Viçosa, MG, Brasil. E-mail: voorwald@gmail.com. *Corresponding author. ${ }^{2}$ Instituto Federal Catarinense (IFC), Araquari, SC, Brasil.

${ }^{3}$ Autônoma, Guaratinguetá, SP, Brasil.

${ }^{4}$ Faculdade de Ciências Agrárias e Veterinárias de Jaboticabal, Universidade Estadual Paulista (FCAV/UNESP), Jaboticabal, SP, Brasil.

ABSTRACT: Thirty and forty days after a $50 \mathrm{mg}$ medroxyprogesterone acetate injection, respectively, two mixed-breed, 7 and 8-month-old entire male cats presented diffuse enlargement of thoracic and abdominal mammary glands, with ulceration, abscessation and necrosis. One patient was treated with $10 \mathrm{mg} / \mathrm{kg}$ aglepristone, antibiotic therapy, analgesic and non-steroidal anti-inflammatory compound; however a worse enlargement of mammary glands, necrosis and clinical condition was noted two days after antiprogestin injection. The second patient was submitted to surgical procedure without previous medical treatment. A partial bilateral mastectomy and conventional orchiectomy were performed, and both patients presented no clinical abnormalities 10 days after surgical treatment. In the male cat, the interruption of progesterone associated mammary fibroepithelial hyperplasia cannot be based in gonadectomy, being antiprogestin treatment the primary approach. Mastectomy can be a treatment option in selected cases, such as the two cases presented here, in case of antiprogestin treatment failure or in case of extensive ulceration, necrosis and risk of sepsis.

Key words: exogenous progesterone, antiprogestin, aglepristone, intact male cat.

Hiperplasia fibroadenomatosa mamária felina secundária à aplicação única de acetato de medroxiprogesterona em dois felinos machos

RESUMO: Trinta e quarenta dias após aplicação de acetato de medroxiprogesterona, dois gatos SRD machos não castrados, de sete e oito meses respectivamente, apresentaram aumento difuso de volume em glândulas mamárias torácicas e abdominais, com ulceração, abscedação e necrose. Um paciente foi tratado com $10 \mathrm{mg} / \mathrm{kg}$ de aglepristone, terapia antimicrobiana, analgésicos e anti-inflamatório não-esteroidal. Entretanto, apresentou piora dos sinais clínicos, da abscedação e necrose dois dias após a aplicação. O outro paciente foi submetido a procedimento cirúrgico sem tratamento clínico prévio. Mastectomia parcial bilateral e orquiectomia convencional foram realizadas e, ambos os pacientes se apresentaram sem alterações clínicas e receberam alta após 10 dias do procedimento cirúrgico. No felino macho, a interrupção da ação da progesterona associada à ocorrência de hiperplasia fibroadenomatosa mamária, não pode ser obtida por meio de gonadectomia, portanto, o tratamento de eleição deve ser realizado com utilização de antiprogestágeno. Em alguns casos, mastectomia parcial ou total é recomendada quando o tratamento clínico com antiprogestágeno falha ou, em casos de sepse, ulceração extensa e necrose, como nos pacientes deste relato. Palavras-chave: progesterona exógena, antiprogestágeno, aglepristone, felino macho não castrado.

\section{INTRODUCTION}

Feline mammary fibroepithelial hyperplasia (MFEH) represents a growth disturbance in cats characterized by the rapid and non-neoplastic proliferation of the ductal epithelium and stroma of the mammary gland. The result is the enlargement of one, several, or all the mammary complexes, that could be reversible (ALLEN, 1973; CONCANNON
\& VERSTEGEN, 2005). The prevalence of this mammary condition depends on socio-economic, political, and cultural characteristics of the locations; it tends to be lower in areas where most cats are neutered prepubertally (PAYAN-CARREIRA, 2013). The disease is a hormone related lesion, characterized by high levels of endogenous progesterone that induces exaggerated mammary glandular tissue proliferation (HAYDEN, et al., 
1989), before puberty, a few weeks after estrus, during pregnancy or pseudopregnancy, or due to exogenous synthetic progestins, such as megestrol acetate (MA) and acetate medroxyprogesterone (MPA) injections, commercially available as a depot contraceptive drug for entire female cats (GÖRLINGER et al., 2002; GRIFFIN, 2001; GUDERMUTH et al., 1997; HAYDEN et al., 1981; HAYDEN, et al., 1989; JELINEK et al., 2007; NOAKES et al., 2018). In male cats, MFEH has been described after MPA or MA injection, considering that these drugs are widely used for a variety of reproductive, behavioral, and dermatologic conditions, or after accidental contact with progestin components in the environment (DORN, et al, 1983; GÖRLINGER et al., 2002; HAYDEN, et al., 1989; JELINEK et al., 2007; LEIDINGER et al., 2011; MACDOUGALL, 2003; MAYAYO, et al., 2018; MEISL, et al., 2003; PAYANCARREIRA, 2013; SONTAS et al., 2008).

The purpose of the present study is to report the successful treatment and outcome of two male cats presenting MFEH after the improper use of a single injection of synthetic progestin.

\section{Case 1 description}

A mixed-breed, seven-month-old, 2.5 $\mathrm{kg}$ entire male cat, was presented with diffuse enlargement of two pairs of abdominal glands (A1, A2) ranging from 7 to $12 \mathrm{~cm}$ in diameter. Physical examination showed that the most severely affected glands were the right abdominal gland and left caudal abdominal gland, which were hyperemic, warm, with prominent dilated veins. The skin was markedly stretched and had a thin, fragile appearance, with signs of abscessation and necrosis (Figure 1A). On clinical examination, the patient revealed a normal rectal temperature and no alterations in mucous membranes, capillary refill time (CRT), pulse rate, and respiratory rate. No signs of discomfort were evident during mammary gland palpation.

According to the patient's owner, 45 days prior to the consultation, one subcutaneous injection of $20 \mathrm{mg} / \mathrm{kg}$ (total $50 \mathrm{mg}$ ) MPA had been administered for prevention of estrus, since the owner believed the animal was a female cat. Two weeks after the injection, the owner noticed an enlargement of the mammary glands and the cat was treated with cefalexin and dexamethasone for ten days. The patient presented a continuous expansive growth and marked enlargement of its mammary glands.

A complete blood count (CBC), chemistry panel, hormonal analysis, and fine needle aspiration biopsy were performed prior to clinical treatment. The hematologic analysis results included leukocytosis $\left(23.0 \times 10^{9} \mathrm{WBCs} / \mathrm{L}\right)$ and neutrophilia (16.86 x $10^{9}$ cells/L). The cat was anemic $\left(4.1 \times 10^{12} \mathrm{RBCs} / \mathrm{L}\right)$ with a low Hct value (28\%) and low hemoglobin concentration $(65 \mathrm{~g} / \mathrm{L})$. The serum biochemical analysis showed no alterations. Results of serum analyses for progesterone and estrogen $(0.92 \mathrm{ng} / \mathrm{mL}$ and $28 \mathrm{pg} / \mathrm{mL}$, respectively) were slightly higher than the basal value for male feline patients and fine needle aspiration biopsy showed lymphoplasmocitary inflammatory infiltrate.

The patient's young age, recent history of progestin administration, and clinical signs in more than one gland indicated that mammary hyperplasia was the most likely diagnosis. Therefore, the patient was treated with subcutaneous injections of 10 $\mathrm{mg} / \mathrm{kg}$ aglepristone (Alizin; Virbac) on day 1 and adjuvant treatment with amoxicillin-clavulanic acid, meloxicam, tramadol $\mathrm{HCl}$, and dipyrone. Two days later, the owner reported the patient became reluctant to walk and anoretic. Findings on physical examination showed worse enlargement of the mammary glands, skin ulceration, abscessation, and necrosis (Figure 1B). Clinical examination revealed a rectal temperature of $39.9^{\circ} \mathrm{C}$, slightly pale mucous membranes, CRT of two seconds, pulse and respiratory rates were normal. Signs of discomfort were evident during ambulation and palpation of the mammary glands. The hematologic analysis revealed a significant increase in leukocytosis $\left(41.0 \times 10^{9} \mathrm{WBCs} / \mathrm{L}\right)$ and neutrophilia $\left(33.12 \times 10^{9}\right.$ cells/L). A coagulation profile test was performed as a preventive measure and the results were normal.

The clinical diagnosis of MFEH, associated with intense inflammation, was confirmed by clinical presentation, as well as by the history of previous use of exogenous progestin. Considering the patient's well-being and the rapid deterioration of clinical conditions, a partial bilateral mastectomy in the caudal thoracic glands (T1, T2), cranial and caudal abdominal glands (A1, A2) was performed under general inhaled anesthesia.

\section{Case 2 description}

A mixed-breed, eight-month-old, $3 \mathrm{~kg}$ entire male cat, presented diffuse enlargement of the caudal thoracic mammary glands (T2), and cranial and caudal abdominal glands (A1, A2) ranging from 9 to $13 \mathrm{~cm}$ in diameter. Findings on physical examination showed that the most severely affected glands were the right caudal thoracic gland and right cranial abdominal gland, which was hyperemic, warm, with granulation tissue, skin ulceration, abscessation, and necrosis (Figure 2A and B). 


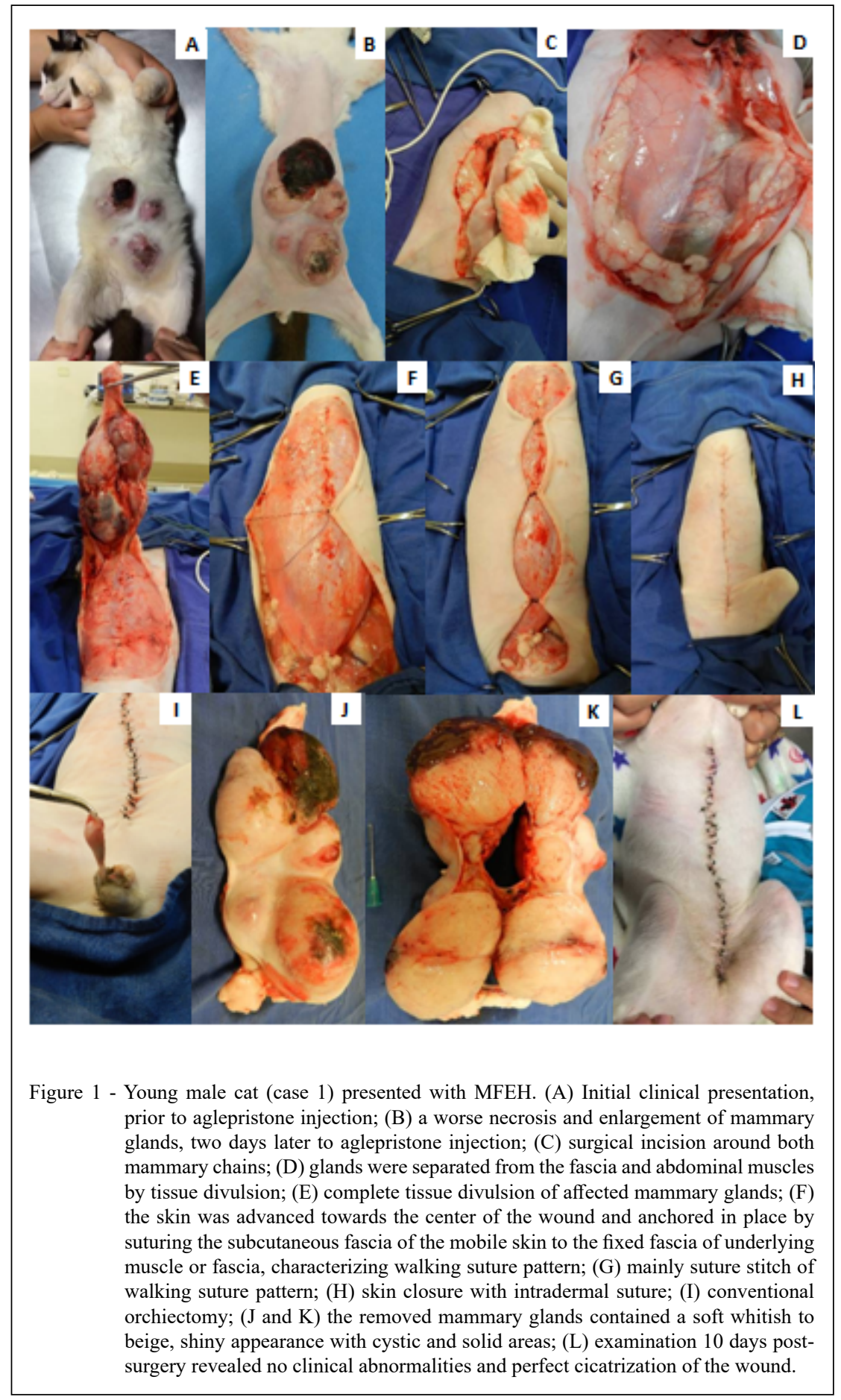

According to the owner, 30 days prior to the consultation, one subcutaneous injection of 20 $\mathrm{mg} / \mathrm{kg}$ (total $60 \mathrm{mg}$ ) MPA had been used to prevent estrus, considering that the previous owner believed the animal was a female cat. Three weeks after the injection, the new owner noticed an enlargement of the mammary glands.

Clinical examination revealed a rectal temperature of $38.9{ }^{\circ} \mathrm{C}$, pale mucous membranes, CRT of two seconds, pulse and respiratory rates were 
normal. Signs of discomfort were evident during ambulation and palpation of the mammary glands. A $\mathrm{CBC}$ and chemistry panel were performed. Results of the hematologic analysis included leukocytosis $\left(31.0 \times 10^{9} \mathrm{WBCs} / \mathrm{L}\right)$ and neutrophilia $\left(22.18 \times 10^{9}\right.$ cells/L). The cat was anemic $\left(3.8 \times 10^{12} \mathrm{RBCs} / \mathrm{L}\right)$ with a low Hct value (26\%) and low hemoglobin concentration $(56.3 \mathrm{~g} / \mathrm{L})$.

The serum biochemical analysis showed no alterations. Due to severe clinical signs, hormonal analysis and fine needle aspiration biopsy were not performed prior to clinical stabilization and treatment.

MFEH aggravated by inflammation and sepsis was diagnosed clinically. Considering the patient's well-being, urgent partial bilateral mastectomy was performed under general inhaled anesthesia.

\section{Surgical procedure}

In both patients, a surgical incision to excise the entire lesion was conducted into both mammary chains (Figure 1C), and the glands were separated from the fascia and abdominal muscles by tissue divulsion (Figure 1C, D, and E). The abscess areas were thoroughly cleaned with sterile saline solution $(0.9 \% \mathrm{NaCl})$. The skin was advanced toward the center of the wound, by using 3-0 poliglecaprone and anchored in place by suturing the subcutaneous fascia of the mobile skin to the fixed fascia of the underlying muscle, characterizing a walking suture pattern (Figure 1F). Several walking sutures were performed (Figure 1G). The incision was closed with an intradermal suture by use of 4-0 poliglecaprone (Figure $1 \mathrm{H}$ ). The cranial thoracic mammary glands were not surgically explored. Both patients were submitted to bilateral conventional orchiectomy, through a routine open technique (Figure 1I), to exclude the presence of a hormone-secreting testicular tumor (BENAZZI et al., 2004; MILLER et al., 2007; MAYAYO et al., 2018).

In both cats, the mammary glands weighed $650-800 \mathrm{~g}$, approximately $25 \%$ of the total body weight. After surgery, the patients were subsequently treated with amoxicillin-clavulanic acid $(20 \mathrm{mg} / \mathrm{kg}$ twice daily, orally administered for 14 days), tramadol $\mathrm{HCl}(2 \mathrm{mg} / \mathrm{kg}$ twice daily, orally administered for 7 days $)$, and meloxicam $(0.05 \mathrm{mg} / \mathrm{kg}$ once a day, orally administered for 3 days).

On macroscopic examination, the mammary glands had a soft whitish to beige, shiny appearance with cystic and solid areas (Figure 1J and $\mathrm{K}$, and Figure 2C). Mammary tissues and testicles were submitted to histological examination. The samples were placed in $10 \%$ buffered formalin and stained with hematoxylin and eosin. Microscopic findings were consistent with diffuse fibroepithelial hyperplasia characterized by different levels of proliferation in both the intralobular mammary duct epithelium and interlobular stroma, composed of fibroblasts and collagen fibers. Myoepithelial cells were concentrically disposed around proliferating ducts. Areas of necrosis, hemorrhage, and neutrophilic infiltrates were observed contiguous

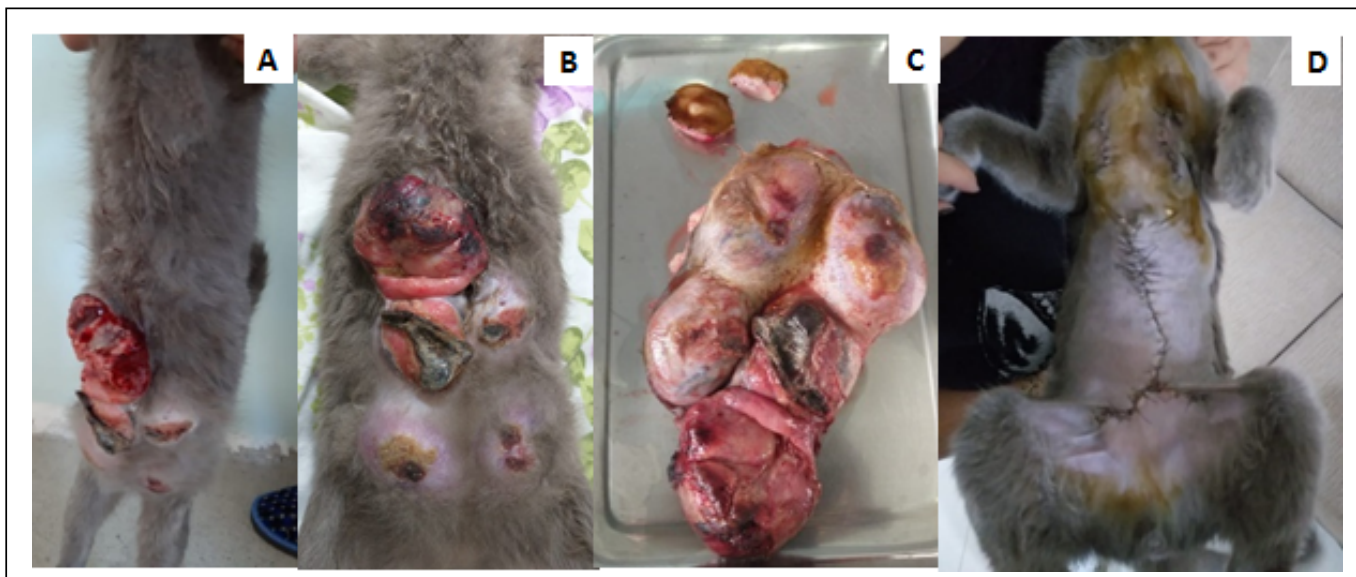

Figure 2 - Young male cat (case 2) presented with MFEH. (A and B) Initial clinical presentation, (C) the removed mammary glands contained a soft whitish to beige, shiny appearance with cystic and solid areas; (D) examination 10 days post-surgery revealed no clinical abnormalities and perfect cicatrization of the wound. 
and beneath the ulcerated and inflamed areas. A definitive histopathologic diagnosis of fibroepithelial hyperplasia in the mammary glands with no evidence of malignancy or neoplastic proliferation was made in both cases. The testicular histological examination was normal in both cats, excluding the presence of a hormone-secreting testicular tumor.

An examination was carried out ten days post-surgery and revealed no clinical abnormalities in either cat and perfect cicatrization of the wounds, with no intercurrence (Figure 1L and Figure 2D).

\section{DISCUSSION}

Cats with fibro-adenomatous hyperplasia have the most typical presentation of one or multiple enlarged mammary glands, which can be edematous, painful, and sometimes, so large that they impair walking, without milk production. The tissue volume increase may result in perfusion problems, ischemia, ulceration, and necrosis, leading to systemic illness CONCANNON \& VERSTEGEN, 2005; GÖRLINGER et al., 2002; JELINEK et al., 2007; WEHREND, et al., 2001)

MFEH diagnosis should be based on wound appearance and patient history that can be supported by an increase of progesterone levels in the patient's blood, reported recent progestin treatment, cytological and histological examination (JOHNSTON, et al., 2001; PAYAN-CARREIRA, 2013; SORENMO, et al., 2019).

Differential diagnosis includes mammary neoplasia, acute mastitis, and hormone-secreting testicular tumor (MILLER et al., 2007; BURSTYN, 2010; MELER et al., 2011). Based on the patient's age, recent history of progestin injection, disease progression, inflammation and infection in more than one gland, presumptive diagnosis of MFEH and early sepsis was made and it was possible to exclude any differential diagnosis including mammary neoplasia by histological analysis.

The exact pathogenesis of fibroepithelial hyperplasia in cats remains unclear; although, it is proposed that the interaction of progesterone or synthetic progestins with progesterone receptors stimulates local growth hormone expression in the mammary gland (DAUGHADAY, et al., 1989; HAYDEN et al., 1981; MARTÍN DE LAS MULAS et al., 2000; MOL et al., 1996; ORDÁS, J. et al., 2004; WEHREND, HOSPES, \& GRUBER, 2001). The growth hormone would act in a potential autocrine/ paracrine stimulatory loop, inducing synthesis of intermediate compounds such as insulin-like growth factor-1 and somatotropin, stimulating a strong mitogenic and anti-apoptotic effect, resulting in proliferation of mammary epithelial and stromal cells (DIAS PEREIRA et al., 2004; MARTÍN DE LAS MULAS et al., 2000; ORDÁS, J. et al., 2004).

According to scientific reports, continuous therapy or repeated doses of synthetic progestin induces MFEH in cats (HAYDEN, et al. 1989; LORETTI et al., 2005). Cases of MFEH associated with a single injection of a synthetic progestin have rarely been reported (LORETTI et al., 2005; MEISL, et al., 2003). A single intramuscular injection in depot form of MPA can maintain levels of this compound for six months (LORETTI et al., 2005), 25 times greater activity than endogenous progesterone (HAYDEN, et al., 1989), and pharmaceutical companies recommend $50 \mathrm{mg}$ for one female cat every six months, regardless of body weight. According to recommendations of scientific manuscripts ( $2.0 \mathrm{mg} / \mathrm{kg}$ every five months) (ROMAGNOLI \& CONCANNON, 2003), this could be considered overdosing, since the patients received $20 \mathrm{mg} / \mathrm{kg}$ (total $50 \mathrm{mg}$ ) in a single injection.

In Brazil, contraceptive therapy with depot injectable progestin has frequently been used in canine and feline veterinary clinical practices; and consequently, clusters of mammary hyperplasia cases have been described in female cats (LORETTI et al., 2004). However, the animal's gender should not be an exclusion criterion, since fibroepithelial hyperplasia also develops in male cats (DORN, LEGENDRE, \& MCGAVIN, 1983; GÖRLINGER et al., 2002; HAYDEN, et al., 1989; JELINEK et al., 2007; LEIDINGER et al., 2011; MACDOUGALL, 2003; MAYAYO, et al, 2018; MEISL, HUBLER, \& ARNOLD, 2003; PAYAN-CARREIRA, 2013; SONTAS et al., 2008) considering that MA and MPA is widely used in small animal medicine for a variety of reproductive, behavioral, and dermatologic conditions (MACDOUGALL, 2003), such as feline eosinophilic and proliferative keratopathies (DORN, LEGENDRE \& MCGAVIN, 1983; MACDOUGALL, 2003), as an appetite stimulant (RIVIERE \& PAPICH, 2018), to suppress inter-cat aggression, urine marking behavior in intact male cats, or temporary and reversible suppression of sexual activity in tom-cats (WEHREND, et al., 2001; GÖRLINGER et al., 2002; JELINEK et al., 2007; LEIDINGER et al., 2011; MACDOUGALL, 2003; MAYAYO, et al, 2018).

PAYAN-CARREIRA (2013) reports three cases of fibroepithelial hyperplasia in young male cats, even with no voluntary administration of progesterone reported by the owner. However, according to MAYAYO et al. (2018), progestin is a 
component of contraceptive pills, some creams and lotions, and may be reported in different types of plants in the environment, and accidental contact with these substances is a plausible explanation for the cat's clinical signs with no history of progestin use, due to the full remission of hyperplasia after aglepristone therapy.

The most suitable therapeutic approach should be selected according to each patient and clinical presentation. As MFEH is a non-neoplastic progesterone-associated disorder, it is possible for most situations to apply in female patients; ovariectomy, ovariohysterectomy, or medical antiprogestin treatment (GÖRLINGER et al., 2002; PAYAN-CARREIRA, 2013; PUKAY \& STEVENSON, 1983), associated in some cases with adjunctive treatments including systemic broad-spectrum antibiotics, analgesics, and anti-inflammatories (LORETTI et al., 2005; OGILVIE $\&$ MOORE, 2001). Aglepristone, the antiprogestin drug, is not licensed for use in cats; however, it has been used for feline patients in several cases reports. The treatment was well tolerated; the only adverse effect described being a scratch at the injection site (GOERICKE-PERSH et al., 2010).

The hyperplastic lesions usually regress within 3-4 weeks after gonadectomy or medical treatment, but remission can take up to 5-6 months (GÖRLINGER et al., 2002; JOHNSTON, et al., 2001). Considering that gonadectomy has the disadvantage of irreversible loss of fertility and the conventional ventral approach is not always recommended due to mammary enlargement, the progesterone antagonist aglepristone (Alizin; Virbac) remains the elective medical treatment (GÖRLINGER et al., 2002; MEISL, et al., 2003; WEHREND, et al., 2001).

Two different protocols using aglepristone have been suggested; $10 \mathrm{mg} / \mathrm{kg}$ for $4-6$ consecutive days (WEHREND, et al., 2001) or $20 \mathrm{mg} / \mathrm{kg}$ once a week or $10 \mathrm{mg} / \mathrm{kg}$ twice a week, until complete remission is achieved (GÖRLINGER et al., 2002), which is preferable considering the prolonged biological half-life of the depot progestin(WEHREND et al., 2001; GÖRLINGER et al., 2002). In our study, a single injection of $10 \mathrm{mg} / \mathrm{kg}$ was not effective to stop MFEH progression and the patient presented two days later, prior to the second aglepristone application, in a worse clinical condition, probably due to progression of the systemic inflammatory response. A partial mastectomy was performed to interrupt inflammation, necrosis, and sepsis progression. The other patient was not submitted to medical treatment, due to its critical clinical presentation.

PAYAN-CARRERA (2012) asserted that it is possible to avoid mastectomy in some patients.
However, regional or bilateral mastectomy is highly recommended when other options have failed or in cases with extensive ulceration and necrosis (CHISHOLM, 1993; GIMÉNEZ et al., 2010; JOHNSTON, et al., 2001; PAYAN-CARREIRA, 2013), such as the patients in this case report.

Besides the benign hyperplasic condition, it should be mentioned that malignant mammary tumors have been reported in male and female cats treated with synthetic progestins (HERNANDEZ et al., 1975; LORETTI et al., 2005; MISDORP, 1991), considering that it increases mammary growth hormone production, implicated as a mediator of progestin-induced mammary epithelial proliferation and tumorigenesis (GARDEREN et al., 1997; MOL et al., 1996; RIJNBERK \& MOL, 1997; SKORUPSKI et al., 2005).

Several reports in the literature associate MPA administration in male cats with the development of mammary adenocarcinomas (SKORUPSKI et al., 2005; JACOBS et al., 2010). This drug was described as efficacious for a variety of behavioral, dermatologic, and reproductive conditions in cats; however, veterinarians should consider the risk of inducing mammary neoplasia with MPA use versus alternate treatment options (JACOBS et al., 2010).

In conclusion, starting treatment with antiprogestin drugs does not guarantee an improvement of patient clinical condition, and the co-existence of ulceration, abscess, necrosis, and systemic illness worsen the prognosis and mastectomy must be performed in those cases to avoid systemic inflammatory response syndrome and sepsis.

\section{ACKNOWLEDGMENTS}

The research was financed in part by the Coordenação de Aperfeiçoamento de Pessoal de Nível Superior (CAPES), Brazil - Finance code 001 .

\section{BIOETHICS AND BIOSSECURITY COMMITTEE APPROVAL}

This research involved the use of non-experimental animals only (owned) and established internationally recognized high standards ('best practice') of individual veterinary clinical patient care were used. Ethical approval from a committee was not necessarily required.

\section{Informed Consent}

Informed consent (either verbal and written) was obtained from the owner or legal custodian of all animals described in this research for the procedures undertaken.

Inform Consent for Publications

No animals or humans are identifiable within this publication; and therefore, additional informed consent for publication was not required. 


\section{DECLARATION OF CONFLICT OF INTERESTS}

The authors declared no potential conflicts of interest with respect to the research, authorship, and/or publication of this article.

\section{AUTHORS' CONTRIBUTIONS}

FAV, CL and DTL managed the cases, provide the clinical data and conducted the analyses. FAV prepared the draft of the manuscript. GCS, MFCS, NBA and GHT provided assistance during the clinical treatment. All authors critically revised the manuscript and approved of the final version.

\section{REFERENCES}

ALLEN, H. L. Feline mammary hypertrophy. Veterinary Pathology, 26 nov. 1973. v.10, n.6, p.501-508. Available from: $<$ http://journals.sagepub.com/doi/10.1177/030098587301000603 >. Accessed: Jun. 23, 2019. doi: 10.1177/030098587301000603.

BENAZZI, C. et al. Sertoli cell tumour in a cat. Journal of Veterinary Medicine Series A: Physiology Pathology Clinical Medicine, 1 abr. 2004. v.51, n.3, p.124-126. Available from: $<$ http://doi.wiley.com/10.1111/j.1439-0442.2004.00608.x >. Accessed: Aug. 27, 2020. doi: 10.1111/j.14390442.2004.00608.x.

BURSTYN, U. Management of mastitis and abscessation of mammary glands secondary to fibroadenomatous hyperplasia in a primiparturient cat. Journal of the American Veterinary Medical Association, 1 fev. 2010. v.236, n.3, p.326-329. Available from: $<$ https://pubmed.ncbi.nlm.nih.gov/20113246/>. Accessed: Nov. 4, 2020. doi: $10.2460 /$ javma.236.3.326.

CHISHOLM, H. Massive mammary enlargement in a cat. The Canadian veterinary journal $=\mathrm{La}$ revue veterinaire canadienne, maio. 1993. v.34, n.5, p.315. Available from: <http:// www.ncbi.nlm.nih.gov/pubmed/17424230>. Accessed: Aug. 27, 2020 .

CONCANNON, P. W.; VERSTEGEN, J. Some unique aspects of canine and feline female reproduction important in Veterinary Practice. Mexico City, Mexico: [s.n.], 2005. Available from: $<$ https://www.vin.com/apputil/content/defaultadv1.aspx?meta $=\mathrm{Ge}$ neric\&pId=11196\&id=3854214>. Accessed: Aug. 27, 2020.

DAUGHADAY, W. H.; ROTWEIN, P. Insulin-like growth factors I and II. Peptide, Messenger Ribonucleic Acid and Gene Structures, Serum, and Tissue Concentrations*. Endocrine Reviews, 1 fev. 1989. v.10, n.1, p.68-91. Available from: $<$ https://academic.oup. com/edrv/article-lookup/doi/10.1210/edrv-10-1-68>. Accessed: Aug. 27, 2020. doi: 10.1210/edrv-10-1-68.

DIAS PEREIRA, P. et al. Cell proliferation in feline normal, hyperplastic and neoplastic mammary tissue - an immunohistochemical study. The Veterinary Journal, 1 set. 2004. v.168, n.2, p.180-185. Available from: < https://linkinghub. elsevier.com/retrieve/pii/S1090023303002065>. Accessed: Aug. 27, 2020. doi: 10.1016/j.tvj1.2003.10.018.

DORN, A. S. et al. Mammary hyperplasia in a male cat receiving progesterone. Journal of the American Veterinary Medical Association, 15 mar. 1983. v.182, n.6, p.621-2. Available from:
$<$ http://www.ncbi.nlm.nih.gov/pubmed/6833110>. Accessed: Aug. $27,2020$.

GARDEREN, E. VAN, et al. Expression of growth hormone in canine mammary tissue and mammary tumors. Evidence for a potential autocrine/paracrine stimulatory loop. The American journal of pathology, mar. 1997. v.150, n.3, p.1037-47. Available from: <http://www.ncbi.nlm.nih.gov/pubmed/9060840>. Accessed: Oct. $11,2019$.

GIMÉNEZ, F. et al. Early detection, aggressive therapy. Optimizing the management of feline mammary masses. Journal of Feline Medicine and Surgery, 1 mar. 2010. v.12, n.3, p.214 224. Available from: <http://journals.sagepub.com/doi/10.1016/j. jfms.2010.01.004>. Accessed: Aug. 27, 2020. doi: 10.1016/j. jfms.2010.01.004.

GOERICKE-PESCH, S. et al. Prevention of pregnancy in cats using aglepristone on days 5 and 6 after mating. Theriogenology, 15 jul. 2010. v.74, n.2, p.304-310. Available from: <https://linkinghub. elsevier.com/retrieve/pii/S0093691X1000107X>. Accessed: Aug. 27, 2020. doi: 10.1016/j.theriogenology.2010.02.014.

GÖRLINGER, S. et al. Treatment of Fibroadenomatous Hyperplasia in Cats with Aglépristone. Journal of Veterinary Internal Medicine, 1 nov. 2002. v.16, n.6, p.710-713. Available from: $<$ http:// doi.wiley.com/10.1111/j.1939-1676.2002.tb02412.x>. Accessed: Aug. 27, 2020. doi: 10.1892/0891-6640(2002)016<0710:tofhic $>$ 2.3.co;2.

GRIFFIN, B. Prolific cats: The estrous cycle. Scott-Ritchey Research Center, Auburn, AL, 2001. v.23, n.12, p.1049-1057. Available from: <http://assets.prod.vetlearn.com.s3.amazonaws. $\mathrm{com} / \mathrm{mmah} / \mathrm{c} 8 / 4524$ e 5 b 2 f8 4140 bc 3 aa $42 \mathrm{fdf} 307687 /$ filePV_23_12_1049.pdf>. Accessed: Nov. 04, 2020.

GUDERMUTH, D. F. et al. Incidence of spontaneous ovulation in young, group-housed cats based on serum and faecal concentrations of progesterone. Journal of reproduction and fertility. Supplement, 1997. v.51, p.177-84. Available from: $<$ http://www.ncbi.nlm.nih.gov/pubmed/9404283>. Accessed: Nov. 04, 2020.

HAYDEN, D. W. et al. Feline mammary hypertrophy/fibroadenoma complex: clinical and hormonal aspects. American journal of veterinary research, out. 1981. v. 42, n. 10, p. 1699-1703. Available from: <http:/www.ncbi.nlm.nih.gov/pubmed/7198885>. Accessed: 04 nov. 2020.

HAYDEN, D. W. et al. Morphologic changes in the mammary gland of Megestrol Acetate-treated and untreated cats: a retrospective study. Veterinary Pathology, 26 mar. 1989. v.26, n.2, p.104-113. Available from: <http://journals.sagepub.com/doi/10.1177/030098 588902600202>. Accessed: Aug. 27, 2020.

HERNANDEZ, F. J. et al. Feline mammary carcinoma and progestogens. Feline practice, 1975. v.5, n.5, p.45-8. Available from: < http://www.ncbi.nlm.nih.gov/pubmed/12258224>. Accessed: Oct. $11,2019$.

JACOBS, T. M. et al. Mammary adenocarcinomas in three male cats exposed to medroxyprogesterone acetate (1990-2006). Journal of Feline Medicine and Surgery, 1 fev. 2010. v.12, n.2, p.169-174. Available from: <http://journals.sagepub.com/ doi/10.1016/j.jfms.2009.08.004>. Accessed: Aug. 27, 2020. doi: 10.1016/j.jfms.2009.08.004. Epub 2009 Oct 8. 
JELINEK, F. et al. Gynaecomastia in a tom-cat caused by cyproterone acetate: a case report. Veterinární Medicína, 7 jan. 2007. v.52, n.No. 11, p.521-525. Available from: $<$ http://www. agriculturejournals.cz/web/vetmed.htm? volume $=52 \&$ firstPage $=521 \&$ type $=$ publishedArticle $>$. Accessed: Aug. 27, 2020. doi: 10.17221/2065-VETMED.

JOHNSTON, S. et al. Canine and feline theriogenology. [S.1.]: WB Saunders, 2001. Available from: <https://books.google. com.br/books/about/Canine_and_Feline_Theriogenology. html?id=boRUZ8V-D3YC\&redir esc=y>. Accessed: Nov. 04, 2020

LEIDINGER, E. et al. Fibroepithelial hyperplasia in an entire male cat: cytologic and histopathological features. Tierärztliche Praxis Ausgabe K: Kleintiere / Heimtiere, 5 jan. 2011. v.39, n.03, p.198-202. Available from: <http://www.thieme-connect.de/DOI/ DOI?10.1055/s-0038-1623578>. Accessed: Aug. 27, 2020.

LORETTI, A. P. et al. Clinical and pathological study of feline mammary fibroadenomatous change associated with depot medroxyprogesterone acetate therapy. Arquivo Brasileiro de Medicina Veterinária e Zootecnia, abr. 2004. v.56, n.2, p.270-274. Available from: <http://www.scielo.br/scielo. php? script $=$ sci_arttext\&pid=S0102-09352004000200020\&1ng =en\&tlng=en>. Accessed: Aug. 27, 2020. doi: 10.1590/S010209352004000200020

LORETTI, A. P. et al. Clinical, pathological and immunohistochemical study of feline mammary fibroepithelial hyperplasia following a single injection of depot medroxyprogesterone acetate. Journal of Feline Medicine \& Surgery, 11 fev. 2005. v.7, n.1, p.43-52. Available from: <http:// $\mathrm{jfm}$.sagepub.com/lookup/doi/10.1016/j.jfms.2004.05.002>. Accessed: Aug. 27, 2020. doi: 10.1016/j.jfms.2004.05.002.

MACDOUGALL, L. D. Mammary fibroadenomatous hyperplasia in a young cat attributed to treatment with megestrol acetate. The Canadian Veterinary Journal, mar. 2003. v.44, n.3, p.227-9. Available from: $<$ http://www.pubmedcentral.nih.gov/articlerender. fcgi?artid=PMC340082>. Accessed: Nov. 04, 2020.

MARTÍN DE LAS MULAS, J. et al. Oestrogen and progesterone receptors in feline fibroadenomatous change: an immunohistochemical study. Research in Veterinary Science, fev. 2000. v.68, n.1, p.15-21. Available from: $<$ https://linkinghub. elsevier.com/retrieve/pii/S0034528899903272>. Accessed: Nov. 04, 2020. doi: 10.1053/rvsc.1999.0327.

MAYAYO, S. L. et al. Mammary fibroadenomatous hyperplasia in a male cat. Journal of Feline Medicine and Surgery Open Reports, 5 jan. 2018. v.4, n.1, p.205511691876015. Available from: <http://journals.sagepub.com/doi/10.1177/2055116918760155>. Accessed: Jun. 25, 2019. doi: 10.1177/2055116918760155.

MEISL, D. et al. Der rogesteronantagonist aglépristone (Alizine ${ }^{\circledR}$ ) zur behandlung der fibroepithelialen hyperplasie der mamma bei der katze. Schweizer Archiv für Tierheilkunde, 1 mar. 2003. v.145, n.3, p.130-136. Available from: <http://sat.gstsvs.ch/de/pu bmed/?doi=10.1024/0036-7281.145.3.130>. Accessed: Aug. 27, 2020. doi: 10.1024/0036-7281.145.3.130.

MELER, E. N. et al. Cyclic estrous-like behavior in a spayed cat associated with excessive sex-hormone production by an adrenocortical carcinoma. Journal of Feline Medicine and Surgery, 1 jun. 2011. v.13, n.6, p.473-478. Available from:
$<$ http://journals.sagepub.com/doi/10.1016/j.jfms.2011.02.002>. Accessed: Aug. 27, 2020. doi: 10.1016/j.jfms.2011.02.002.

MILLER, M. A. et al. Interstitial cell tumor and Sertoli cell tumor in the testis of a cat. Veterinary Pathology, 26 maio. 2007. v.44, n.3, p.394-397. Available from: <http://journals.sagepub.com/ doi/10.1354/vp.44-3-394>. Accessed: Aug. 27, 2020. doi: 10.1354/ vp.44-3-394.

MISDORP, W. Progestagens and mammary tumours in dogs and cats. Acta endocrinologica, 1991. v.125, n.1, p.27-31. Available from: <http://www.ncbi.nlm.nih.gov/pubmed/1839343>. Accessed: Nov. 04, 2020.

MOL, J. A. et al. New insights in the molecular mechanism of progestin-induced proliferation of mammary epithelium: Induction of the local biosynthesis of growth hormone $(\mathrm{GH})$ in the mammary gland of dogs, cats and humans. The Journal of Steroid Biochemistry and Molecular Biology, 1 jan. 1996. v.57, n.1-2, p.67-71. Available from: <https://inkinghub.elsevier.com/ retrieve/pii/0960076095002510>. Accessed: Aug. 27, 2020. doi: 10.1016/0960-0760(95)00251-0.

NOAKES, D. E. et al. Arthur's Veterinary Reproduction and Obstetrics. 10. ed. [S.1.]: Elsevier Health Sciences, 2018. Available from: $\quad<$ https://www.elsevier.com/books/arthurs-veterinaryreproduction-and-obstetrics $/ 9780702025563$ ?aaref $=$ https $\% 3 \mathrm{~A} \% 2$ F\%2Fwww.google.com\%2F>. Accessed: Nov. 04, 2020.

OGILVIE, G.; MOORE, A. Feline oncology: a comprehensive guide to compassionate care. [S.1.]: Wiley-Blackwell, 2001. Available from: <https://books.google.com.br/books/about/ Feline_Oncology.html?id=LA0ekgEACAAJ\&redir_esc $=y>$. Accessed: Nov. 04, 2020.

ORDÁS, J. et al. Immunohistochemical expression of progesterone receptors, growth hormone and insulin growth factor-I in feline fibroadenomatous change. Research in Veterinary Science, jun. 2004. v.76, n.3, p.227-233. Available from: <https://linkinghub. elsevier.com/retrieve/pii/S0034528803002261>. Accessed: Nov. 04, 2020. doi: 10.1016/j.rvsc.2003.11.006.

PAYAN-CARREIRA, R. Feline Mammary Fibroepithelial Hyperplasia: A Clinical Approach. In: PAYAN-CARREIRA, R. (Org.). Insights from Veterinary Medicine. Rijeka: InTech, 2013, p. 215-233. Available from: <https://www.intechopen. com/books/insights-from-veterinary-medicine/feline-mammaryfibroepithelial-hyperplasia-a-clinical-approach>. Accessed: Nov. 04, 2020. doi: 10.5772/55550.

PUKAY, B. P.; STEVENSON, D. A. Mammary hypertrophy in an ovariohysterectomized cat. The Canadian veterinary journal $=$ La revue veterinaire canadienne, maio. 1983. v.24, n.5, p.143-4. Available from: <http://www.ncbi.nlm.nih.gov/ pubmed/17422254>. Accessed: Aug. 27, 2020.

RIJNBERK, A.; MOL, J. A. Progestin-induced hypersecretion of growth hormone: an introductory review. Journal of reproduction and fertility. Supplement, 1997. v.51, p.335-8. Available from: <http://www.ncbi.nlm.nih.gov/ pubmed/9404303>. Accessed: Nov. 04, 2020.

RIVIERE, J. E.; PAPICH, M. G. Veterinary pharmacology and therapeutics. 10. ed. Iowa: John Wiley \& Sons, 2018. Available from: <https://www.wiley.com/en-us/Veterinary + Pharmacology+and+Therapeutics $\% 2 \mathrm{C}+10$ th+Edition-p- 
9781118855881\#: :text=Veterinary\%20Pharmacology $\% 20$ and $\% 20$ Therapeutics\%2C\%20Tenth,a11\%20 major\%20 domestic\%20animal\%20species>. Accessed: Nov. 04, 2020.

ROMAGNOLI, S.; CONCANNON, PW. Clinical use of progestins in bitches and queens: a review. Recent advances in small animal reproduction. Ithaca: International Veterinary Information Service, 2003. Available from: <https://www. ivis.org/library/recent-advances-small-animal-reproduction/ clinical-use-of-progestins-bitches-and-queens-a-0>. Accessed: Nov. 04, 2020.

SKORUPSKI, K. A. et al. Clinical characteristics of mammary carcinoma in male cats. Journal of Veterinary Internal Medicine, 1 jan. 2005. v.19, n.1, p.52-55. Available from: <http://doi.wiley. com/10.1111/j.1939-1676.2005.tb02658.x>. Accessed: Aug. 27, 2020. doi: 10.1892/0891-6640(2005)19<52:ccomci $>2.0$. co;2.
SONTAS, B. H. et al. What is your diagnosis? Journal of Small Animal Practice, 1 out. 2008. v.49, n.10, p.545-547. Available from: <https://pubmed.ncbi.nlm.nih.gov/18844825/>. Accessed: Nov. 04, 2020. doi: 10.1111/j.1748-5827.2008.00637.x.

SORENMO, K. U. et al. Tumors of the mammary gland. In: VAIL, D. M. et al. Withrow and MacEwen's Small Animal Clinical Oncology-E-Book. 6. ed. St. Louis, Missouri: Elsevier Health Sciences, 2019, Chap. 28. p.604-625. Available from: <https:// www.vetsmall.theclinics.com/article/S0195-5616(03)00020-2/pdf $>$. Accessed: Nov. 04, 2020. doi: 10.1016/S0195-5616(03)00020-2.

WEHREND, A. et al. Treatment of feline mammary fibroadenomatous hyperplasia with a progesterone-antagonist. Veterinary Record, 17 mar. 2001. v.148, n.11, p.346-347. Available from: $<$ https://veterinaryrecord.bmj.com/content/148/11/346>. Accessed: Aug. 27, 2020. doi: 10.1136/vr.148.11.346. 